\title{
Molecular Cloning, Expression Analysis and Enzymatic Characterization of Elastase-like Serine Protease from the Olive Flounder (Paralichthys olivaceus)
}

\author{
Jin-Wook HAN $\cdot$ Jung-Soo SEO · Sang-Jung AHN $^{*} \cdot$ Jin-Young LEE $\cdot$ Ju-Hyeon PARK \\ Na-Young KIM* $\cdot$ Moo-Sang $\mathrm{KIM}^{* *} \cdot$ Jee-Youn HWANG ${ }^{*} \cdot$ Joon-Ki CHUNG $\cdot$ Hyung-Ho LEE ${ }^{\dagger}$
}

(Pukyong National University $\cdot{ }^{*}$ National Fisheries Research and Development Institute $\cdot{ }^{* *}$ Dongseo University)

\section{넙치로부터의 Serine Protease의 분자생물학적 클로닝, 발현, 특성분석}

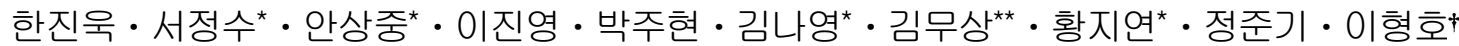 \\ (부경대학교 • ${ }^{*}$ 국립수산과학원 · ${ }^{* *}$ 동서대학교)
}

\begin{abstract}
넙치 (Paralichthys olivaceus)로부터 elastase-like serine protease (PoElSp)를 암호화하는 cDNA를 클로 닝하여 그 서열을 분석한 결과, PoElSp 유전자는 269 아미노산을 암호화하는 978 염기쌍으로 구성되었 다. PoElSp 유전자의 조직 특이적 발현 양상을 RT-PCR법으로 조사한 결과, 간, 비장 및 소장에서 그 발현이 크게 나타났다. lipopolysaccharide (LPS)로 인위적 세균감염을 유도한 후, 1 시간째에 콩팥에서, 3시간째에는 근육에서, PoElSp 유전자의 발현이 크게 증가하였다. 또한, 이 유전자의 발현은 비장에서 LPS 주입 후 1-24시간동안 점차로 증가하였다. pro-mature PoElSp (proPoElSp)에 해당하는 cDNA를 $\mathrm{pET} 32 \mathrm{a}$ 벡터 시스템을 이용하여 대장균에서 발현시켰다. 이 재조합 proPoEISp 단백질의 활성은 gelatin zymography 방법과 합성형광 Z-Phe-Arg-AMC의 분해법을 이용하여 측정하였다. 단백질 분해효 소 활성을 위한 최적 $\mathrm{pH}$ 는 7.5 였다. 실험결과들을 종합하면, PoEISp 단백질은 면역 반응에서 중추적 역할을 하리라 판단된다.
\end{abstract}

Key words : Elastase-like serine protease, Olive flounder, Paralichthys olivaceus, RT-PCR, Zymography

\section{I . Introduction}

Proteases are currently classified into four major classes, serine, cysteine, aspartic, and metallo proteases (Barrett et al., 1998). Proteases are involved in numerous important physiological processes including protein turnover, digestion, blood coagulation and wound healing, fertilization, cell differentiation, cell signaling, immune response and apoptosis (Barrett et al., 1998; Powers et al., 2002).

Serine proteases are one of the most thoroughly understood enzyme families, and all serine proteases contain an active site termed the catalytic triad, which consists of His, Asp and Ser amino acid residues. They are found ubiquitously in both eukaryotes and prokaryotes. The serine residue at the active site participates in the formation of a

$\uparrow$ Corresponding author : 051-629-5864, hyunghl@pknu.ac.kr

※ 이 논문은 부경대학교 자율창의학술연구비(2013년)에 의해 운영되었음. 
transient acyl-enzyme intermediate between the substrate and the protease (Kraut, 1977; Parry et al., 1998; Perona et al., 1995; Piao et al., 2007). Serine protease cascades amplify signals from physiological or pathological responses in the extracellular milieu of vertebrate and invertebrates (Piao et al., 2005). In mammals, a complex cascade of coagulation factors, most of which are serine proteases, is triggered upon tissue injury to prevent bleeding. The complement system also employs similar protease cascades in response to microbial infection (O'Brien et al., 1993). Serine proteases fall into two broad categories based on their structures, chymotrypsin-like or subtilisin-like serine proteases. Chymotrypsin-like serine proteases are characterized by a distinctive structure, consisting of two beta-barrel domains that converge at the catalytic active site. These enzymes can be further categorized based on their substrate specificity as either trypsin-like, chymotrypsin-like or elastase-like (Ovaere et al., 2009).

In contrast, elastase-like serine protease has not been completely characterized with regard to its enzymatic properties and physiological functions except its molecular and phylogenetic characterization from teleosts including Atlantic cod (Gadus morhua) (Gudmundsdóttir et al., 1996), Japanese flounder (Paralichthys olivaceus) (Suzuki et al., 2002) and zebrafish (Danio rerio) (Wan et al., 2006). In this study, we described the cDNA cloning, tissue-typical mRNA expression, and enzymatic characterization of the recombinant elastase-like serine protease in the olive flounder (P. olivaceus).

\section{II . Materials and methods}

\section{1. cDNA Synthesis and Rapid Amplification of cDNA Ends (RACE)}

The total RNA was isolated from olive flounder using the TRIzol ${ }^{\circledR}$ (Invitrogen) according to the manufacturer's instructions, and cDNA was synthesized from this isolated mRNA using the Transcriptor First Strand cDNA Synthesis Kit (Roche). In an effort to identify the elastase-like serine protease of the olive flounder, regions around the highly conserved region of elastase-like serine protease (sense primer, pro-ElSp-F; antisense primer; pro-ElSp-R, [Table 1]) were utilized in the amplification of cDNAs from an olive flounder cDNA mixture. Rapid amplification of cDNA ends (RACE) was used to clone the cDNA containing 5'- and 3'-end of PoElSp using a SMART ${ }^{\mathrm{TM}}$ RACE cDNA amplification kit (Clontech). The 5'-end of the PoElSp gene was obtained by 5' RACE-PCR using the specific primer sets PoElSp-GSP-R1 with Universal Primer Mix (UPM) for first round-PCR and PoElSp-GSP-R2 primer with Nested Universal Primer (NUP) for second nested PCR, respectively. The two primer sets used for 3' RACE-PCR were PoElSp-3'-F1 primer with UPM and PoElSp-3'-F2 primer with NUP [Table 1] for obtaining 3'-end region. After amplification, the RACE products were subcloned into a pGEM $^{\circledR}$ T-Easy vector (Promega), and then transformed into E. coli DH5 $\alpha$ competent cells according to the manufacturer's instructions. The E. coli clones containing the recombinants were overlaid with $100 \mu \mathrm{g} / \mathrm{ml}$ of ampicillin, $0.4 \mathrm{mM}$ isopropyl- $\beta$-thiogalactopyranoside (IPTG) and $40 \mu \mathrm{g} / \mathrm{ml}$ 5-bromo-4-chloro-3-indoly- $\beta$ -D-galactoranoside (X-Gal) in the Luria-Bertani (LB) agar plate. White colonies were randomly chosen, cultivated and used for extraction of plasmid DNA. Plasmid DNA was prepared from $E$. 
Jin-Wook HAN • Jung-Soo SEO • Sang-Jung AHN • Jin-Young LEE • Ju-Hyeon PARK • Na-Young KIM Moo-Sang KIM $\cdot$ Jee-Youn HWANG $\cdot$ Joon-Ki CHUNG $\cdot$ Hyung-Ho LEE

coli using a LaboPass ${ }^{\mathrm{TM}}$ Plasmid Mini Purification Kit (COSMO GENETECH). DNA sequencing was conducted using T7 promoter/ SP6 primers in the SolGent Co., Ltd.

$<$ Table 1> Oligonucleotide primers used for PoEISp amplification and expression studies

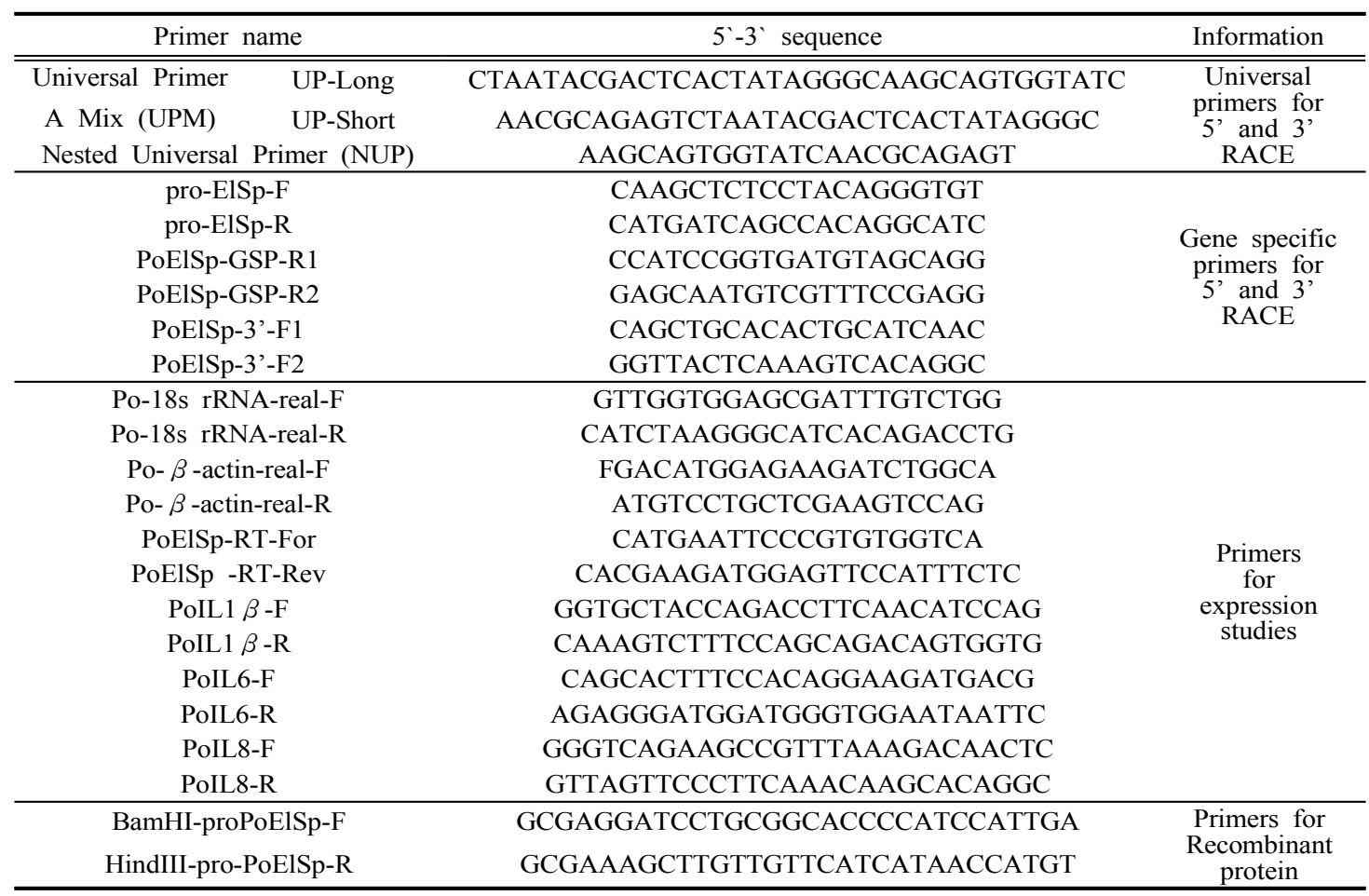

\section{Sequence and Phylogenetic Analysis}

Nucleotide and predicted amino acid sequences of PoElSp were analyzed using DNAsis for Windows version 2.5 (Hitachi software engineering), BioEdit Sequence Alignment Editor (Hall, 1999) and BLAST programs in the National Center for Biotechnology Information (http://www.ncbi.nlm. nih.gov/BLAST/). The signal sequence and putative cleavage site of PoElSp was identified using the SignalP 4.0 (http://www.cbs.dtu.dk/services/SignalP).

Predictions of the pro-region cleavage sites and active sites were based on alignment of the elastase-like serine protease sequences with the vertebrate orthologues. Multiple sequence alignments of PoElSp with other serine proteases were constructed using BioEdit Sequence Alignment Editor with CLUSTAL W version 1.9 (Thompson et al., 1994). The phylogenetic tree was constructed using the Neighbor-Joining method and plotted with MEGA version 4.1 (Kumar et al., 2008).

\section{Expression Studies by RT-PCR and Quantitative Real-Time PCR}

In order to visualize the expression patterns of the PoElSp mRNA, RT-PCR and quantitative real-time PCR were conducted using total RNAs from brain, eye, gill, heart, gullet, liver, spleen, pyloric ceca, stomach, intestine, kidney and muscle tissues obtained from healthy specimens of $P$. olivaceus. The total RNA was isolated using 
TRIzol $^{\mathbb{B}}$ (Invitrogen) in accordance with the manufacturer's instructions, and the purified RNA was quantified via optical density at $260 \mathrm{~nm}$ using a UV spectrophotometer (Ultrospec 6300 pro, Amersham Biosciences). Two micrograms of total RNA from the $P$. olivaceus tissues was reverse-transcribed with Transcriptor First Strand cDNA Synthesis Kit (Roche). The specific primers for olive flounder elastase-like serine protease (PoElSp), PoElSp-RT-For and PoElSp-RT-Rev primers were used for RT-PCR and real-time PCR <Table 1>. $P$. olivaceus $\beta$-actin was utilized as the internal control (Po $\beta$-actin-real-F and Po $\beta$-actin-real-R primer set for the flounder $\beta$-actin, $(<$ Table $1>$ ).

All of the PCR was run as follows: $94{ }^{\circ} \mathrm{C}$ for 5 min, 30 cycles of $94{ }^{\circ} \mathrm{C}$ for $30 \mathrm{~s}, 55^{\circ} \mathrm{C}$ for $20 \mathrm{~s}$ and $72{ }^{\circ} \mathrm{C} 30 \mathrm{~s}$, and a final $7 \mathrm{~min}$ of elongation at $72{ }^{\circ} \mathrm{C}$. The resultant PCR products were separated on $1.2 \%$ agarose/TAE gels containing ethidium bromide and visualized with a Gel Doc image analysis system (Bio-Rad). The PCR products were purified via agarose gel extraction (QIAquick ${ }^{\circledR}$ Gel Extraction kit) and sequenced (SolGent Co., Ltd., DNA Sequencing Service).

To examine the immune responses and expression regulation of PoElSp gene, lipopolysaccharide (LPS) from E. coli 0127: B8 (Sigma-Aldrich, USA) was used to induce inflammatory responses in the various flounder tissues (gill, kidney, spleen and muscle). Gene expression in LPS-stimulated PoElSp gene was compared with the expression of cytokines, IL- $\beta$ (PoIL1 $\beta-\mathrm{F}$ and PoIL1 $\beta-\mathrm{R}$ for the flounder IL-1 $\beta$ ), IL-6 (PoIL6-F and PoIL6-R for the flounder IL-6) and IL-8 (PoIL8-F and PoIL8-R for the flounder IL-8) genes, which were utilized as internal controls for inducible gene expression <Table 1>. LPS was intraperitoneally injected at a concentration of 0.02 $\mathrm{mg} / \mathrm{g}$ body mass. Three fish (average mass $100 \mathrm{~g}$ ) were sacrificed after 1, 3, 6 and $24 \mathrm{~h}$ of injection. Total RNA isolation, reverse transcription, PCR reaction and direct DNA sequencing were performed as described above. Quantitative PCR was conducted using SYBR 480 Real-Time PCR (Roche) with SYBR Green (Roche applied science). Each reaction contained the following: $10 \mu 1$ of the Power SYBR ${ }^{\circledR}$ Green PCR Master Mix (Roche applied science), 0.2 $\mu \mathrm{M}$ primer sets, $0.5 \mathrm{cDNA}$ (300 ng), and water to a final volume of $20 \mu \mathrm{l}$. The PCR parameters were as follows: initial denaturation at $95{ }^{\circ} \mathrm{C}$ for $5 \mathrm{~min}$ to activate DNA polymerase. The melting curve cycles were conducted under the following conditions: followed by 40 cycles of $10 \mathrm{~s}$ at $95{ }^{\circ} \mathrm{C}, 10 \mathrm{~s}$ at 60 ${ }^{\circ} \mathrm{C}$, and $10 \mathrm{~s}$ at $72{ }^{\circ} \mathrm{C}$. All of the data were gathered from triplicate experiments and were expressed as fluorescence relative to $\beta$-actin. The relative fold change of PoElSp expression was determined by the $2^{-\Delta \Delta \mathrm{Ct}}$ method as described previously (Giulietti et al., 2001; Livak et al., 2001).

\section{Expression and Purification of Recombinant proPoEISp Protein}

To prepare an expression vector suitable for the production of recombinant olive flounder elastase-like serine protease in E. coli, a $759 \mathrm{bp}$ DNA fragment containing the coding sequence for the pro-mature form of $P$. olivaceus elastase-like serine protease (proPoElSp) was generated by PCR amplification. The primers (BamHI-proPoElSp-F, 5'-GCGAGGATCCTGCGGCACCCCATCCATTGA-3'; HindIII-pro-PoElSp-R, 5'-GCGAAAGCTTGTTGT-TCAT CATAACCATGT-3') harbor BamHI/HindIII restriction sites (underlined), allowing for the cloning of the amplified DNA in a predicted orientation into pET32a vector system (Novagen). Recombinant plasmid (proPoElSp/pET32a) was transformed into E. coli strain 
BL21(DE3). Transformed cells were grown in LB broth containing $100 \mathrm{mg} / \mathrm{ml}$ ampicillin at $37^{\circ} \mathrm{C}$ for approximately $16 \mathrm{hr}$, diluted $1 / 100$ with the same medium, and grown to an $\mathrm{A}_{600}$ of 0.6. Next, isopropyl$\beta$-D-thiogalactopyranoside (IPTG) was added to a final concentration of $0.4 \mathrm{mM}$, and the incubation was continued for $3 \mathrm{hr}$ at $18{ }^{\circ} \mathrm{C}$. Cells were collected by centrifugation, washed, and resuspended in 0.2 volumes of phosphate buffered saline, and then sonicated. After, cell lysates are centrifuged at $20,000 \times \mathrm{g}$ for $20 \mathrm{~min}$ at $4^{\circ} \mathrm{C}$, the supernatant fraction was applied to the His-bind column. After twice washing of column with $1 \mathrm{x}$ wash buffer $(20 \mathrm{mM}$ Tris/pH 7.9, $60 \mathrm{mM}$ imidazole, $0.5 \mathrm{M} \mathrm{NaCl}$ ), recombinant proPoElSp protein was eluted in ten fractions with $1 \mathrm{x}$ elution buffer $(20 \mathrm{mM}$ Tris/pH 7.9, $1 \mathrm{M}$ imidazole, $0.5 \mathrm{M}$ $\mathrm{NaCl}$ ). The pooled fractions were dialyzed and analyzed by SDS-PAGE, western blotting and enzyme activity assay. Protein concentration was determined with a Bio-Rad protein assay kit.

\section{SDS-PAGE, Western Blotting and Zymography}

Purified proPoElSp enzyme was analyzed by $12 \%$ SDS-PAGE. All samples were denatured in a buffer containing $60 \mathrm{mM}$ Tris $/ \mathrm{pH} \quad 6.8,25 \%$ glycerol, $2 \%$ SDS, $\quad 14.4 \mathrm{mM}$ 2-mercaptoethanol and $0.1 \%$ bromophenol blue, boiled for $5 \mathrm{~min}$, and separated by $12 \%$ SDS-PAGE (Bio-Rad). After electrophoresis, the gel was stained with Coomassie brilliant blue R-250. Western blotting was performed using mouse monoclonal anti-His antibody (1: 2000, Santa Cruz Biotechnology). The substrate zymography was performed by a modified procedure using gels with gelatin (Sigma) as described earlier (Heussen el al., 1980) with slight modifications. To prepare the zymography, $30 \mathrm{ul}$ of a protease sample was mixed with $10 \mathrm{ul}$ of $4 \mathrm{x}$ SDS-sample buffer $(0.5 \mathrm{M}$ Tris/pH
6.8, 10\% SDS, $20 \%$ glycerol and $0.02 \%$ bromophenol blue). The sample was then applied to the gel and electrophoresed using a Bio-Rad Mini-PROTEAN ${ }^{\circledR}$ system (Bio-Rad) with a constant current of $12 \mathrm{~mA}$ per gel at $4^{\circ} \mathrm{C}$. After electrophoresis, the gels were immersed in $100 \mathrm{ml}$ of $2.5 \%(\mathrm{v} / \mathrm{v})$ Triton $\mathrm{X}-100$ for $1 \mathrm{~h}$ to remove SDS and were washed once with incubation buffer (0.1 M Tris/ $\mathrm{pH} 8.0$, containing 1 $\mathrm{mM}$ DTT). Next, the gels were immersed in the incubation buffer for $18 \mathrm{hr}$ at $37^{\circ} \mathrm{C}$. Subsequently, the gels were washed with water and stained in $5 \%$ methanol/10\% acetic acid/ water containing $0.1 \%$ Coommassie Brilliant Blue R-250. Protease bands appeared as clear zones on a blue background.

\section{Enzyme Activity Assays}

The Serine proteases activity was assayed according to the modified method of Barret et al, (1981). The optimum $\mathrm{pH}$ for enzymatic activity of proPoElSp protein was determined using a sodium acetate buffer in $\mathrm{pH}$ ranges of 3-10 with Z-Phe-Arg-7-amido-4methylcoumarin hydrochloride (Z-FR-AMC; Sigma) as substrates. Briefly, $10 \mu l$ of recombinant proPoElSp protein in $85 \mu l$ of $0.1 \mathrm{M}$ Tris/pH 7.5, containing 1 $\mathrm{mM}$ DTT were preincubated at $37^{\circ} \mathrm{C}$ for $2 \mathrm{hr}$, and the enzyme reaction was initiated by adding $5 \mu l$ of 1 $\mathrm{mM}$ Z-FR-AMC at $37^{\circ} \mathrm{C}$ for $10 \mathrm{~min}$. The 7-amido-4-methylcoumarin (AMC) was measured using a Microplate Fluorometer (Packard Co. USA) at an excitation wavelength of $380 \mathrm{~nm}$ and an emission wavelength of $460 \mathrm{~nm}$. Substrate specificities were investigated using Z-Arg-Arg-AMC (Sigma), Z-Gly-Pro-ArgAMC (Sigma), Ala-Ala-Phe-AMC (Sigma), Z-Arg-GlyPhe-Pro-Pro (Sigma), and Suc-Leu-Leu- Val-Tyr-AMC with $0.1 \mathrm{M}$ Tris/ $\mathrm{pH}$ 8.0, and containing $1 \mathrm{mM}$ DTT, respectively. Substrates were added to a final concentration of $100 \mu \mathrm{M}$. 
Molecular Cloning, Expression Analysis and Enzymatic Characterization of Elastase-like Serine Protease from the Olive Flounder (Paralichthys olivaceus)

<Table 2> Sequences used in this study

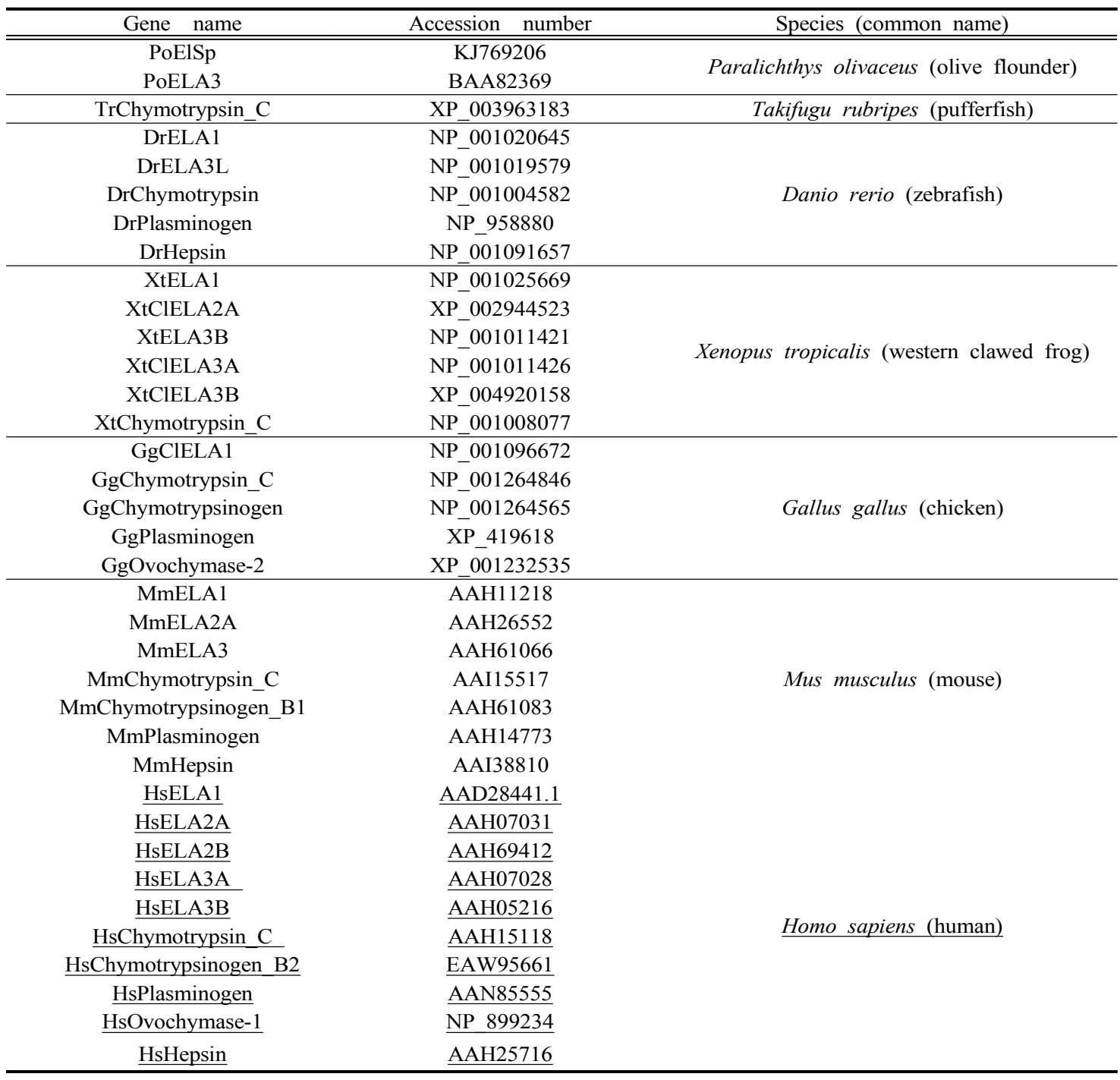

7. Effect of Enzyme Inhibitors, Metal lons and Detergents

The effects of enzyme inhibitors on protease activity were studied using Z-Phe-Arg-AMC as the fluorogenic substrate. The following known proteinase inhibitors were tested: trans-Epoxysuccinyl-L-leucyl-amido (4-guanidino) butane (E-64; Sigma), and Leupeptin (USB Co., USA) for cysteine protease inhibitor; Antipain (Sigma), $N$-ethylmaleimide (NEM; Sigma),
Phenylmethylsulphonyl fluoride (PMSF; Sigma), Chymostatin (Sigma), and Aprotinin (Sigma) for serine protease inhibitor; Ethylene diamine tetraacetic acid (EDTA; Sigma), Ethylene glycol-bis (beta-aminoethylether)-N,N,N',N'-tetraacetic acid (EGTA;Sigma) and 1,10-Phenanthroline (Sigma) for metalloproteinase inhibitor; Pepstatin A (Sigma) for aspartic protease inhibitor. Also, the effect of various metal ions ( 1 and $5 \mathrm{mM})$ on enzyme 
activity was investigated using $\mathrm{CoCl}_{2}, \mathrm{CaCl}_{2}$, $\mathrm{MgSO}_{4}, \mathrm{KCl}, \quad \mathrm{ZnSO}_{4}, \mathrm{CuSO}_{4}$ and $\mathrm{HgCl}_{2}$. The effects of some surfactants (Brij35, TritonX-100, Tween 20 and SDS) on enzyme stability were also examined. The effects of enzyme inhibitors, metal ions and detergents $(0.01$ and $0.05 \%)$ on the activity of proPoElSp protein were studied at $\mathrm{pH}$ 7.5 and $37^{\circ} \mathrm{C}$. The values shown in tables and graphical data represent the mean of three assays ( \pm standard deviation). All the analyses were performed using Microsoft Excel and SigmaPlot software package.

\section{Results and discussion}

\section{Cloning and Sequence Analysis of Olive Flounder Elastase-like Serine Protease}

In order to determine the evolutionary relationship of PoElSp, phylogenetic tree analysis Full-length of P. olivaceus elastase-like serine protease (PoElSp) cDNA was obtained by combining DNA sequences of cDNA library clones and 5' SMART $^{\mathrm{TM}}$ RACE cDNA Amplification PCR product. The full-length

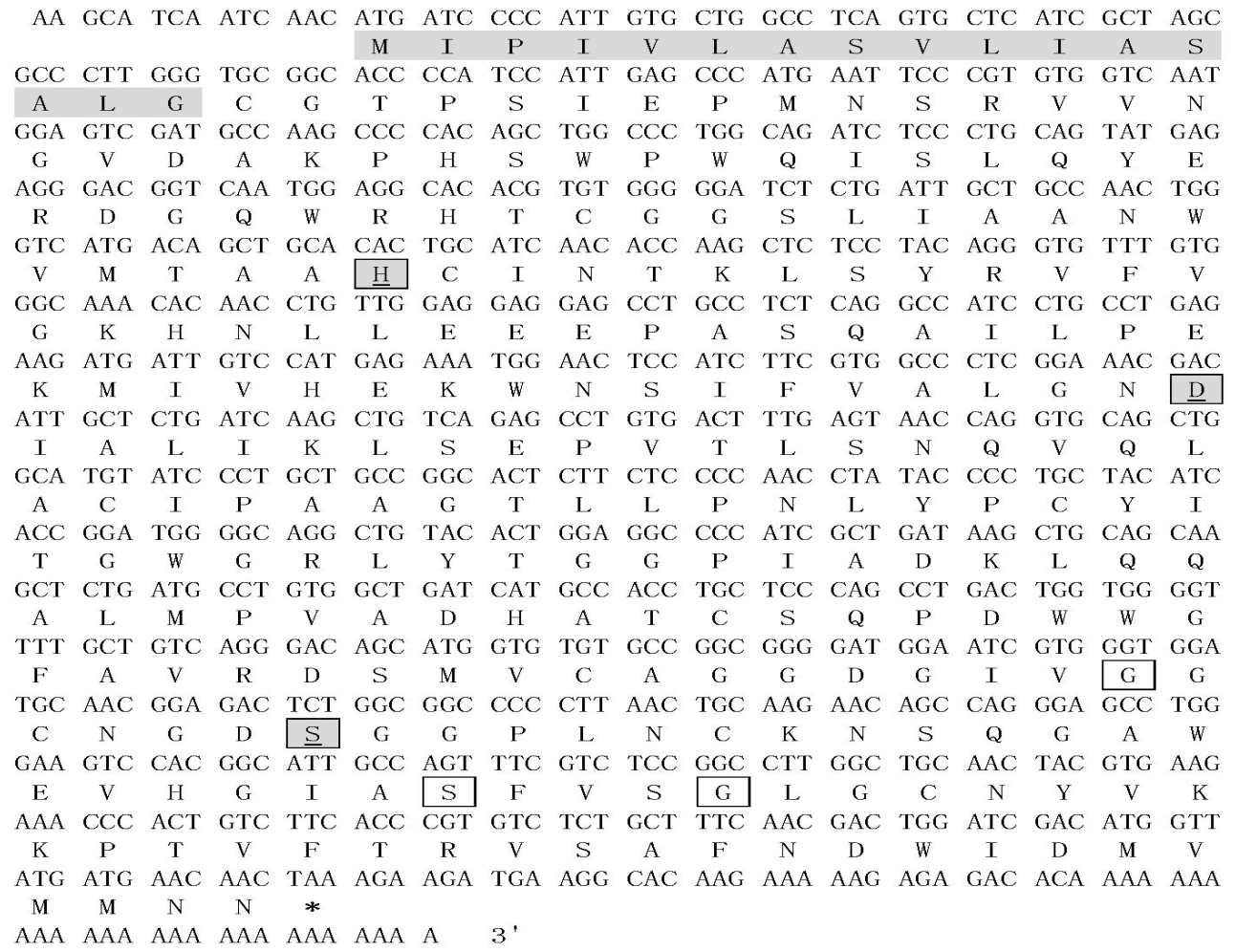

[Fig. 1] Nucleotide and deduced amino acid sequences of Paralichthys olivaceus elastase-like serine proteases (PoEISp). The shaded box and thick underline in the amino acid sequence indicates the putative signal peptide (pre) and the propeptides of PoElSp. The three active site triad residues His45, Asp93 and Ser188 (based on mature PoElSp numbering) are marked with a shaded box and underlined. The amino acid sequences in the open boxes are indicated the substrate binding sites on conserved domain (Gly182, Ser208 and Gly212). The asterisk at the end of the amino acid sequences shows the stop codon. 
cDNA yielded a 978 bp sequence comprised a 110 bp 5'-untranslated region (5'UTR) and a 810 bp coding region including a stop codon (TAA), followed by a 58 bp 3'-untranslated region (3'UTR), including the run of poly (A) sequences presumably derived from the poly (A)-rich tail of the mRNA (Proudfoot and Brownlee, 1976) [Fig. $1]$.

The nucleotide sequence of PoElSp was predicted to encode for a pre-pro-mature protein of 269 amino acids, which contained a 16 residue putative signal peptide analyzed with SignalP 4.0 (Petersen et al., 2011), a 12 residue propeptide and the 241 residue mature enzyme with a calculated molecular mass of 29,040 Da. The sequence of PoElSp was deposited in GenBank under the accession number KJ769206 [Fig. 1].

[Fig. 2] shows the alignment of PoElSp with different serine proteases of human. A comparison of the amino acid sequence of PoElSp with human chymotrypsin C, chymotrypsin-like elastase family, member 1 (ELA1), ELA2A, ELA2B, ELA3A and ELA3B showed 46.5 - 57.3\% identities. As shown in [Fig. 2], each of the catalytic triad residues PoElSp is surrounded by a highly conserved motif. The motif "GDSGGP" surrounds serine, "TAAHC" histidine and DIM/ALL aspartate (Rawlings et al., 1993).

was conducted with the amino acid sequences of vertebrate serine protease families acquired from

PoE1Sp
HsChymotrypsin C
HsELA2A
HsELA2B
HsELA3A
HsELA3B
HsELA1
PoE1Sp
HsChymotrypsin C
HsELA2A
HsELA2B
HsELA3A
HsELA3B
HsELA1
PoE1Sp
HsChymotrypsin C
HsELA2A
HsELA2B
HsELA3A
HsELA3B
HsELA1
PoE1Sp
HsChymotrypsin C
HsELA2A
HsELA2B
HsELA3A
HsELA3B
HsELA1

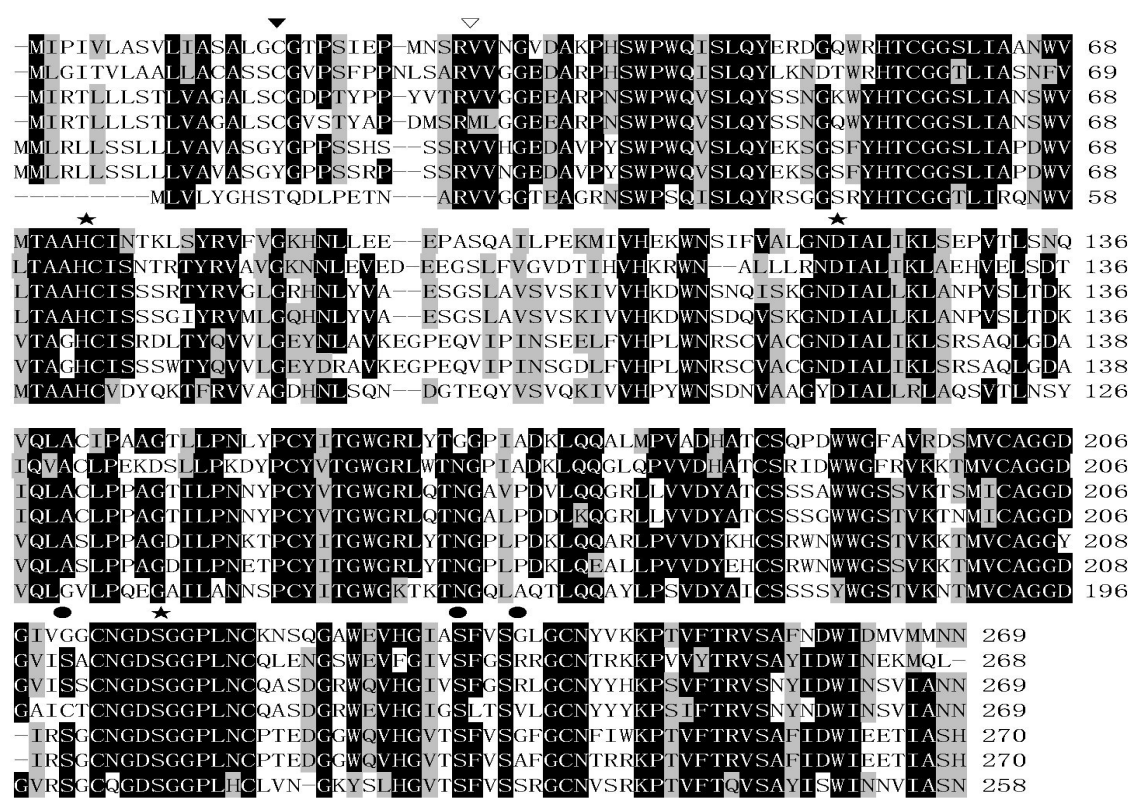

[Fig. 2] Multiple amino acid sequence alignment of $P$. olivaceus elastase-like serine protease with various human serine proteases. Identical amino acid residues are darkly shaded, similar amino acids are lightly shaded, unrelated residues have a white background, and amino acid numbers are shown on the right. The filled and open triangle represents the predicted cleavage sites of the pre- and pro-sequences in Paralichthys olivaceus elastase-like serine protease, respectively. The serine protease catalytic triad residues $(H, D$, and $S)$ are shown with an asterisk. The circles are indicated the substrate binding site of PoEISp (G, $S$ and $G$ ). GenBank accession numbers of all sequences was presented in [Table 2]. 
GenBank via neighbor-joining methods (Saitou et al., 1987) [Fig. 3].

On the basis of a comprehensive phylogenetic analysis, the clades of elastase-like serine protease did not create a monophyletic group. As shown in [Fig. 3], PoElSp was placed closely related vertebrate elastase clades and clustered with a large group of vertebrate serine proteases, including chymotrypsin $\mathrm{C}$, elastase 1 , elastase 2, plasminogen, hepsin, chymotrypsinogen and ovochymase. The results of our phylogenetic analysis showed that the PoElSp clustered with elastase 3 from vertebrates.

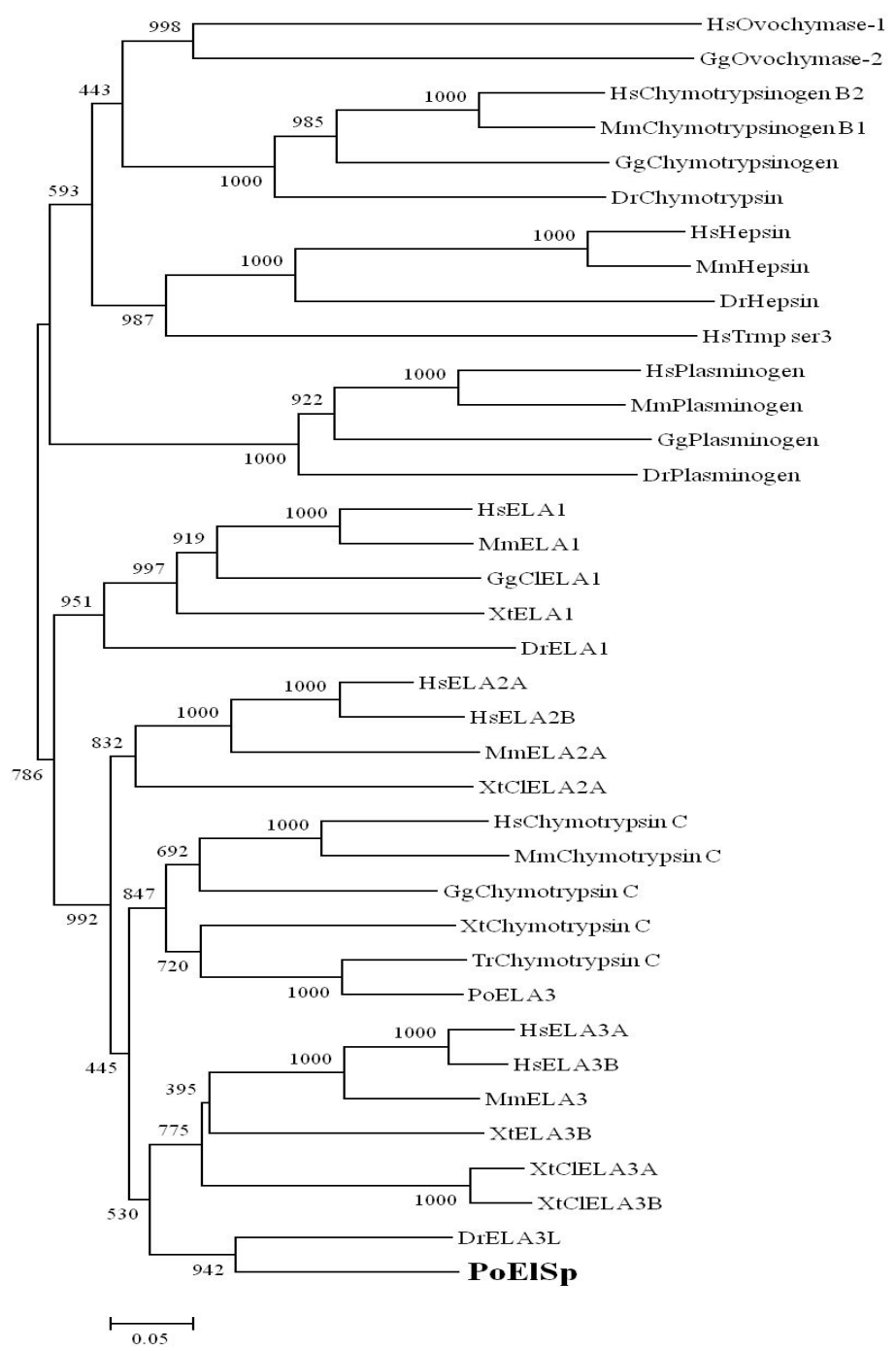

Ovochymase

Chymotrypsinogen

Hepsin

Plasminogen

Elastase 1

Elastase 2

Chymotrypsin C

Elastase 3

[Fig. 3] Phylogenetic relationships of PoElSp among representative mammalian and fish groups based on the elastase-like serine protease genes. In this neighbor-joining phylogram, all individuals are represented and the branches are based on the number of inferred substitutions as indicated by the bar. GenBank accession numbers of all sequences was presented in [Table 2]. 


\section{Tissue Distribution and expression studies of PoEISp mRNA}

To examine the tissue type-specific expression of PoElSp mRNA transcripts in olive flounder tissues. RT-PCR was conducted with PoElSp-specific primers <Table 1>. Relative PoElSp gene expression level was normalized using olive flounder $\beta$-actin and 18S rRNA genes. As is shown in [Fig. 4], PoElSp mRNA was observed in liver tissue with a high expression level. Also, PoElSp mRNA exists in spleen and intestine tissues. Humans have six elastase genes which encode the structurally similar proteins elastase 1, 2, 2A, 2B, 3A, and 3B. Unlike other elastases, elastase 3 has little elastolytic activity, and it has a digestive function in the intestine. Also, elastase may also function in the intestinal transport and metabolism of cholesterol (Tani et al., 1988; Shimada et al., 2002). This result suggests that PoElSp may be somewhat linked to digestive function in the intestine. To study the functional characteristics of PoElSp, we compared the changes in the mRNA expression levels in the kidney, spleen, muscle, and gill tissues after in vivo stimulation (up to $0,1,3,6$ and $24 \mathrm{~h}$ ) with lipopolysaccharide (LPS) using RT-PCR and real time PCR. The interleukin-1 beta (IL-1 $\beta$ ), IL-6 and IL- 8 were chosen as the indicator genes, since

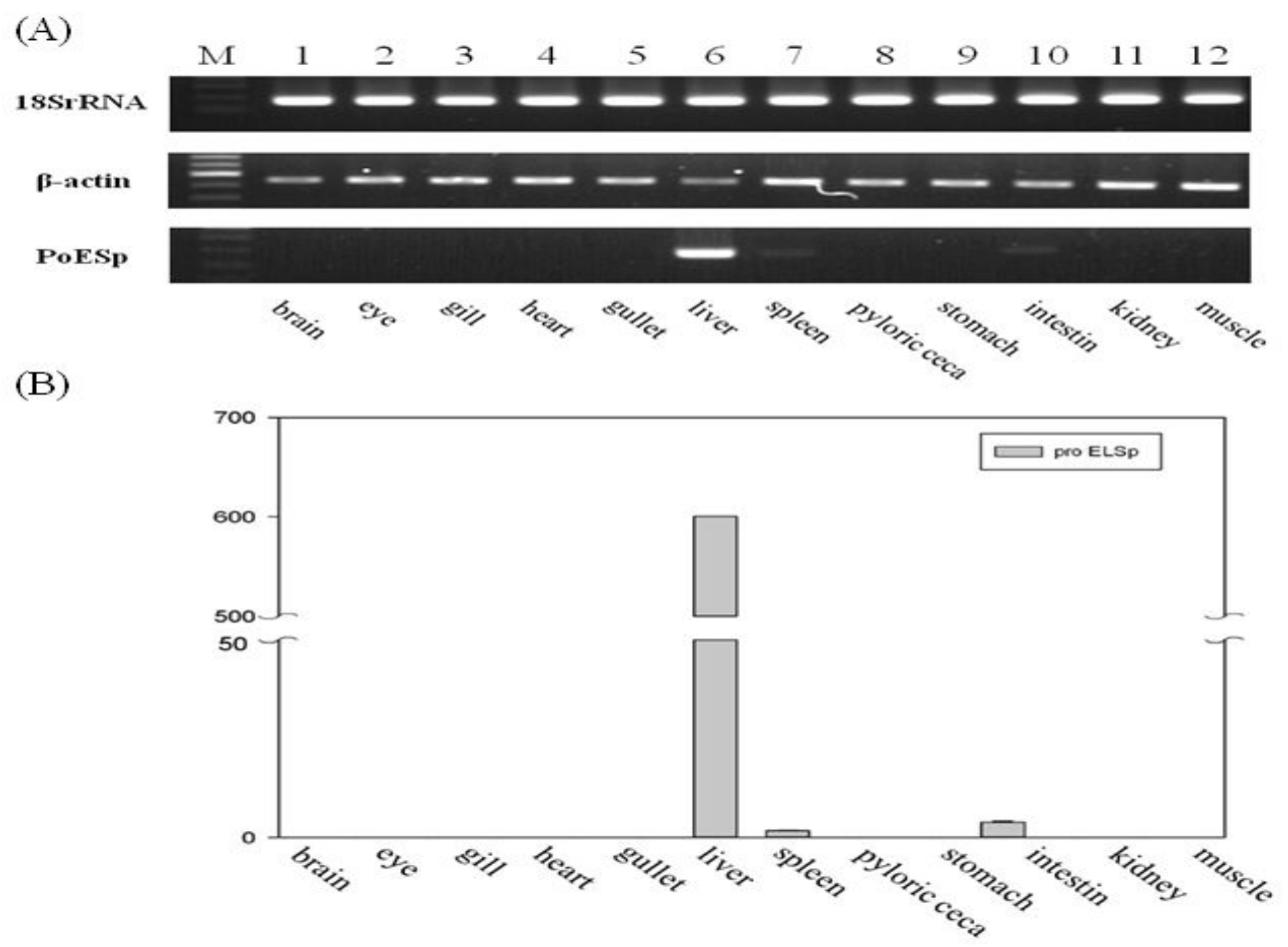

[Fig. 4] Tissue distribution of the Pro-form elastase-like serine protease mRNA. (A) Total RNA was isolated from various Paralichthys olivaceus, and $0.5 \mu \mathrm{g}$ was subjected to RT-PCR analysis using the amplimers for the $P$. olivaceus Pro-form elastase-like serine protease, $\beta$-actin, and 18s rRNA. (B) Quantitative real-time PCR of proPoEISp. 
these genes can be induced by LPS, and are important cytokines and good markers of inflammatory responses (Corripio-Miyar et al., 2007; Zhang et al., 2008). After stimulation with LPS, the levels of IL- $\beta$, IL-6, and IL-8 transcripts varied according to the time post-injection and increased significantly in these tissues $1-6 \mathrm{~h}$ post-injection (HPI), whereas the $\beta$-actin transcripts were expressed at a steady-state level at all times post-injection. The level of PoElSp mRNA was strongly increased expression after 1 HPI in the kidney, 1-24 HPI in the spleen, and 3 HPI in the muscle tissues [Fig. 5]. Therefore, our results showed that PoElSp may be involved in immune defense and responses of olive flounder against bacterial infection (Sonawane et al., 2006).

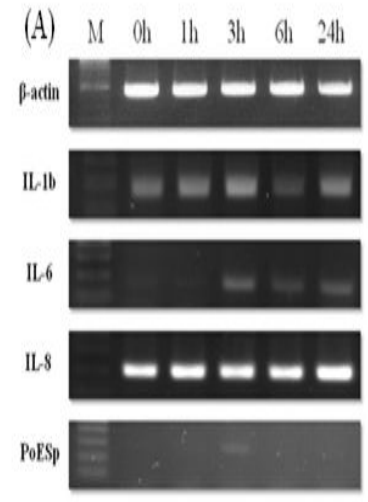

(E)

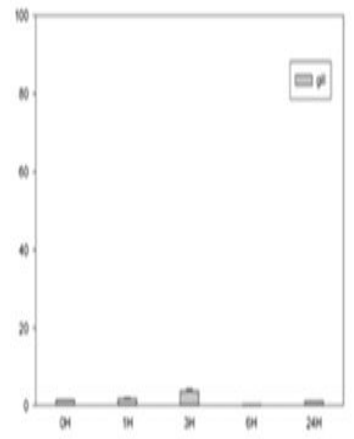

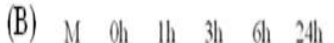
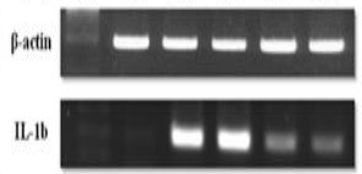

IL6 6
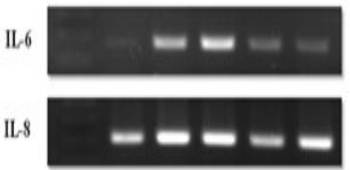

PoESp

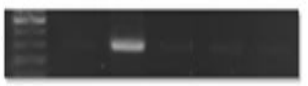

(F)

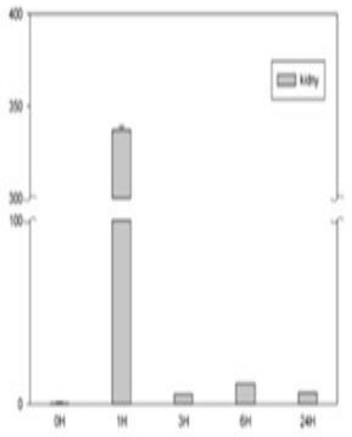

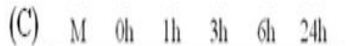

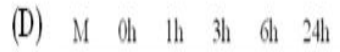

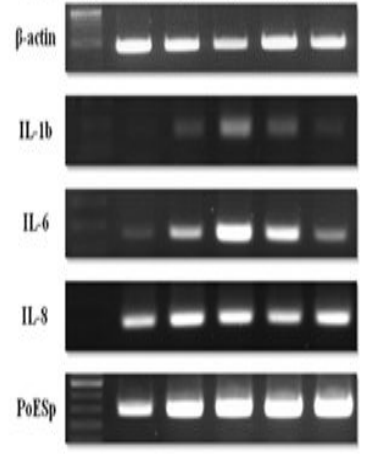

(G)

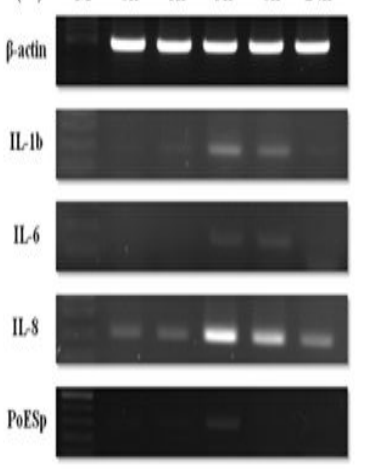

(H)
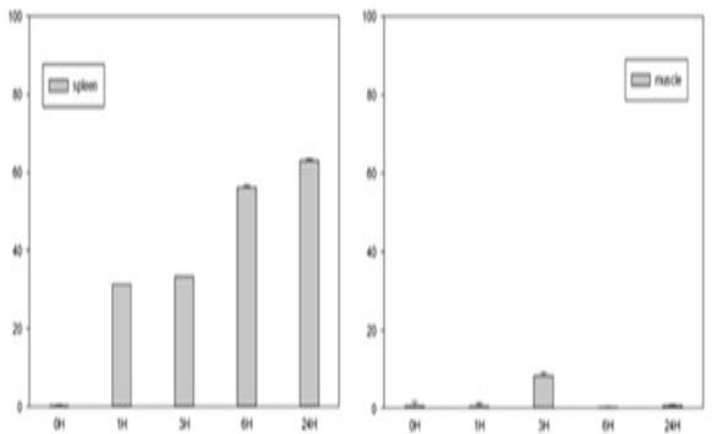

[Fig. 5] Tissue distribution of proPoElSp gene after LPS injection. RT-PCR and real-time PCR analysis after LPS injection between $0,1,3,6$, and $24 \mathrm{~h}$ from gill ( $A$ and $E$ ), kidney ( $\mathrm{B}$ and $\mathrm{F}$ ), spleen $(C$ and $G$ ), and muscle tissues ( $D$ and $H$ ). Mean mRNA levels in olive flounder tissues were analyzed by realtime $P C R$, and $2-\triangle \triangle C$ t levels were calculated relative to the tissue with $0 \mathrm{~h}$ set to 1 , and normalized against $\beta$-actin expression. Each experiment was done in triplicate.

\section{Enzymatic Characterization of Recombinant proPoEISp}

In order to assess the functional and enzymatic characteristics of PoElSp, the cDNA encoding for pro form of PoElSp was expressed in E. coli as a fusion protein with His-tag. The recombinant proPoElSp /pET32a was overexpressed in E. coli BL21(DE3) as a $47 \mathrm{kDa}$ fusion protein. The 
overproduced soluble His-tag fusion protein (proPoElSp) was then applied to His bind column chromatography. The proPoElSp protein band had a high purity and the correct size by SDS-PAGE and Western blot analysis [Fig. 6]. The purified proPoElSp activity was quantified by measuring the cleavage of a synthetic fluorogenic peptide substrate, Z-FR-AMC, and proteolytic activity of recombinant proPoElSp was determined by gelatin zymography. As can be seen in (Fig. 6), the purified proPoElSp was capable of hydrolyzing $0.1 \%$ gelatin, and the recombinant proPoElSp displayed activity over a wide range of $\mathrm{pH}(\mathrm{pH} 7.0$ to 10) with optimal activity occurring at $\mathrm{pH} 7.5$.

\section{(A)}

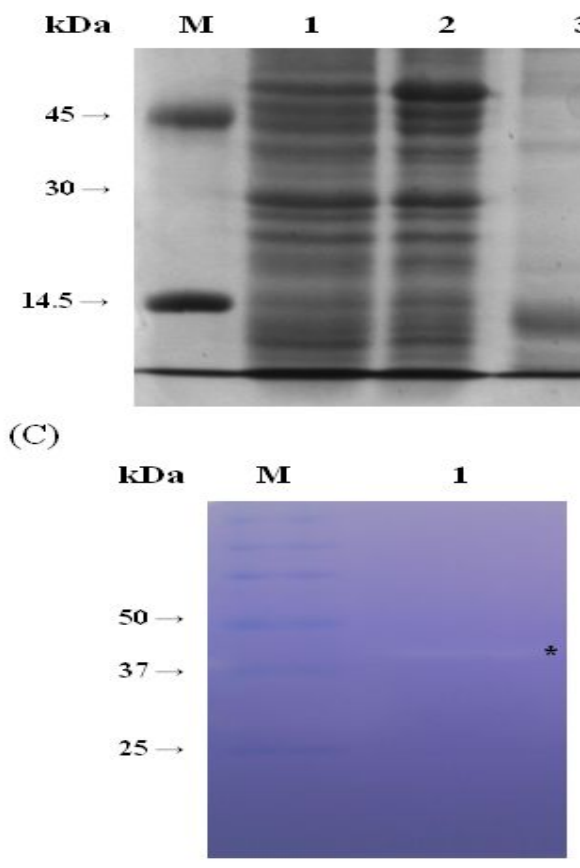

(B)

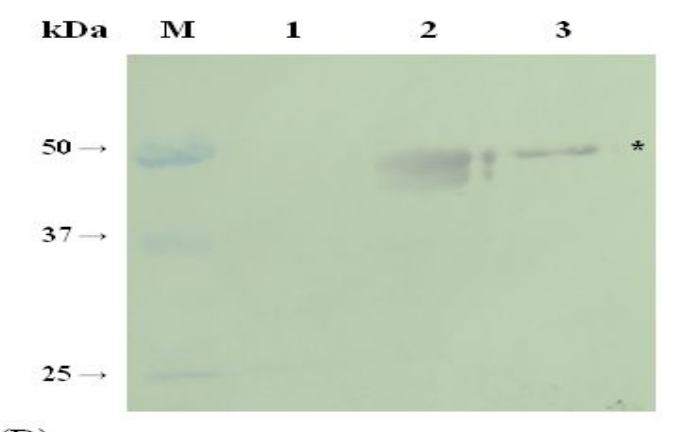

(D)

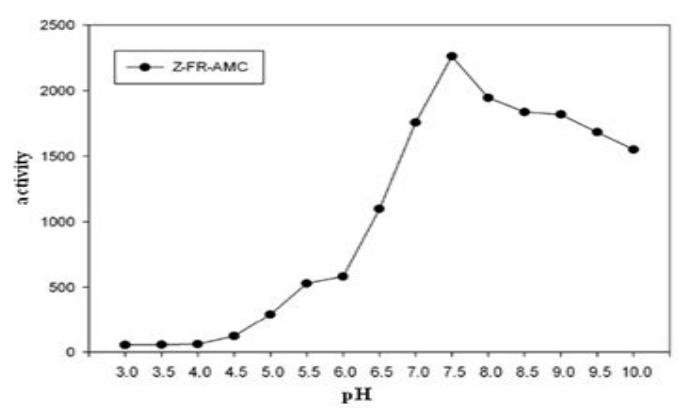

[Fig. 6] Analysis of enzymatic characterization of recombinant proPoPISp. (A) Coomassie blue staining after SDS-PAGE. The lanes were labeled as follows: lane $\mathrm{M}$, standard size marker; lane 1, non-induced proPoEISp; lane 2, IPTG-induced proPoEISp $\left(37^{\circ} \mathrm{C}\right) ; 3$. His tag affinity column purified proPoEISp. (B) Western blot analysis. Lane $\mathrm{M}$, prestained protein size marker; lane 1, non-induced PoEISp (negative control); lane 2, IPTG-induced PoEISp $\left(37^{\circ} \mathrm{C}\right.$ ); lane 3, His tag affinity column purified PoEISp. (C) Gelatin zymography of purified proPoEISp. Lane M, prestained protein size marker; lane 1, purified PoEISp protein. (D) $\mathrm{pH}$ dependence of proPoEISp. Proteolytic activity was assayed against Z-Phe-Arg-AMC. The points show the average values of 3 independent experiments.

We also compared proPoElSp activity on various substrates conjugated with $\mathrm{AMC}$ as the fluorescent chromophore $<$ Table $3>$. The highest levels of AMC release activity were seen from Z-FR-AMC,
Z-RR-AMC, and Z-GPR-AMC.

To identify the function of proPoElSp as a serine protease, the effects of enzyme inhibitors on protease activity were studied using Z-Phe-Arg-AMC 
Jin-Wook HAN · Jung-Soo SEO · Sang-Jung AHN • Jin-Young LEE $\cdot$ Ju-Hyeon PARK • Na-Young KIM Moo-Sang KIM · Jee-Youn HWANG $\cdot$ Joon-Ki CHUNG $\cdot$ Hyung-Ho LEE

\begin{tabular}{ccc}
$\begin{array}{c}\langle\text { Table } 3\rangle \quad \begin{array}{l}\text { Substrate } \\
\text { protein }\end{array} \\
\text { specificity }\end{array}$ of proPoElSp \\
\hline $\begin{array}{c}\text { Substrates } \\
\text { ion }(\mu \mathrm{M})\end{array}$ & Activity (\%) \\
\hline $\begin{array}{c}\text { Z-Phe-Arg-AMC } \\
\text { (FR) }\end{array}$ & 50 & $100.00 \pm 0.52$ \\
$\begin{array}{c}\text { Z-Arg-Arg-AMC } \\
\text { (RR) }\end{array}$ & 50 & $90.55 \pm 0.45$ \\
$\begin{array}{c}\text { Z-Gly-Pro-Arg-AMC } \\
\text { (GPR) }\end{array}$ & 50 & $54.26 \pm 0.36$ \\
$\begin{array}{c}\text { Ala-Ala-Phe-AMC } \\
\text { (AAF) }\end{array}$ & 50 & $9.67 \pm 0.18$ \\
$\begin{array}{c}\text { Z-Arg-Gly-Phe-Pro-Pr } \\
\text { o (RGFP) }\end{array}$ & 50 & $1.95 \pm 0.34$ \\
$\begin{array}{c}\text { Suc-Leu-Leu-Val-Tyr- } \\
\text { AMC (LLVY) }\end{array}$ & 50 & $1.59 \pm 0.67$ \\
\hline
\end{tabular}

as fluorogenic substrate. The following known proteinase inhibitors were tested: trans-EpoxysuccinylL-leucyl-amido (4-guanidino) butane (E-64), antipain, and leupeptin as cysteine protease inhibitors,
N-ethylmaleimide (NEM, phenylmethylsulphonyl fluoride (PMSF), chymostatin, and aprotinin as serine protease inhibitors, ethylene diamine tetraacetic acid (EDTA), ethylene glycol-bis (beta-aminoethyl ether)-N,N,N',N'-tetraacetic acid (EGTA) and 1,10-phenanthroline as metalloproteinase inhibitors, and pepstatin $\mathrm{A}$ as aspartic protease inhibitor. The enzymatic activity of proPoElSp was significantly reduced or blocked by antipain, NEM and PMSF while the other cysteine, aspartic, and metallo-protease inhibitors had low influence on proPoElSp activity [Table 4]. Additionally, many metal ions (at $1 \mathrm{mM}$ and $5 \mathrm{mM}$ ) and detergents (at $0.01 \%$ and $0.05 \%$ ) have been found to have no influence on the activity of proPoElSp, but $\mathrm{CoCl} 2$ led to significant induction in protease activity [Table 5].

$\langle$ Table 4> Effects of various protease inhibitors on the enzymatic activity of the proPoElSp protein. The purified proPoEISp protein was pre-incubated with the indicated inhibitors and assayed for residual activity using Z-Phe-Arg-AMC as the fluorogenic substrate

\begin{tabular}{cccc}
\hline Inhibitors & Specificity & Concentration $(\mathrm{mM})$ & Inhibition (\%) \\
\hline \hline Control & - & - & 0 \\
E-64 & All cysteine proteinases & 0.1 & $33.8 \pm 3.38$ \\
Antipain & Serine/cysteine proteinases & 0.1 & $66.8 \pm 9.54$ \\
Chymostatin & Chemotrypsin & 0.1 & $13.5 \pm 2.33$ \\
Leupeptin & Cysteine/trypsin-like & 0.1 & $32.8 \pm 0.67$ \\
NEM & Serine proteinases & 0.1 & $41.3 \pm 4.17$ \\
PMSF & Serine proteinases & 0.1 & $40.1 \pm 0.53$ \\
Aprotinin & Serine proteinases & 0.1 & $24.6 \pm 1.44$ \\
EDTA & Serine proteinases & 0.1 & $23 \pm 2.01$ \\
EGTA & Metallo proteinases & 0.1 & $25.8 \pm 0.89$ \\
1,10 -phenanthroline & Metallo proteinases & 0.1 & $37.8 \pm 0.212$ \\
Pepstatin A & Metallo proteinases & 0.1 & $0 \pm 2.89$ \\
\hline
\end{tabular}

Here, we report the molecular cloning, sequence analysis, tissue-specific distribution, and enzymatic characterization of a recombinant protein from olive flounder $(P$. olivaceus) elastase-like serine protease 
(PoElSp). To the best of our knowledge, this is the first report on the molecular characteristics and heterologous expression of elastase 3-like serine protease from fish. The results for the tissue-specific expression and enzymatic activity of PoElSp indicate that may explain their importance in digestive function in intestine, and immune defense and responses in the kidney and spleen against bacterial infection.

$\langle$ Table 5> Effect of metal ions and various detergents on activity of proPoEISp protein

\begin{tabular}{ccc}
\hline \multirow{2}{*}{ Agent } & \multicolumn{2}{c}{ Relative activity (\%) } \\
\cline { 2 - 3 } & $1 \mathrm{mM}$ & $5 \mathrm{mM}$ \\
\hline \hline Control & 100.00 & 100.00 \\
$\mathrm{CoCl} 2$ & $254.97 \pm 14.70$ & $218.60 \pm 12.40$ \\
$\mathrm{CaCl} 2$ & $114.36 \pm 0.55$ & $78.99 \pm 2.37$ \\
$\mathrm{MgSO} 4$ & $104.13 \pm 2.37$ & $91.23 \pm 0.57$ \\
$\mathrm{KCl}$ & $94.19 \pm 9.48$ & $84.19 \pm 4.35$ \\
$\mathrm{ZnSO} 4$ & $91.84 \pm 2.84$ & $82.23 \pm 5.53$ \\
$\mathrm{CuSO} 4$ & $80.17 \pm 2.29$ & $53.74 \pm 2.53$ \\
$\mathrm{HgCl} 2$ & $66.48 \pm 8.85$ & $65.08 \pm 0.08$ \\
\cline { 2 - 3 } & $0.01 \%$ & $0.05 \%$ \\
\cline { 2 - 3 } $\mathrm{SDS}$ & $134.53 \pm 14.22$ & $94.25 \pm 0.97$ \\
$\mathrm{Brij}-35$ & $96.31 \pm 2.37$ & $70.95 \pm 1.83$ \\
TritonX-100 & $92.63 \pm 5.69$ & $69.11 \pm 2.66$ \\
Tween20 & $86.54 \pm 13.83$ & $74.92 \pm 2.00$ \\
\hline
\end{tabular}

\section{References}

Barrett, A. J. and Kirschke, H.(1981). Cathepsin B, Cathepsin H, and cathepsin L. Methods in Enzymology 80, 535 561.

Barrett, A. J. - Rawlings, N. D. and Woessner, J. F. (1998). Handbook of Proteolytic Enzymes 19, 340 341. London : Academic.

Corripio-Miyar Y. • Bird, S. • Tsamopoulos, K. • Secombes, C. J.(2007). Cloning and expression analysis of two pro-inflammatory cytokines, IL-1 beta and IL-8, in haddock (Melanogrammus aeglefinus). Molecular Immunology 44, 1361 1373.
Giulietti, A. · Overbergh, L. · Valckx, D. · Decallonne, B. - Bouillon, R. and Mathieu, C.(2001). An overview of real-time quantitative PCR: applications to quantify cytokine gene expression. Methods 25, 386 401.

Gudmundsdóttir, E. · Spilliaert, R. · Yang, Q. · Craik, C. S. - Bjarnason, J. B. and Gudmundsdóttir, A.(1996). Isolation and characterization of two cDNAs from Atlantic cod encoding two distinct psychrophilic elastases. Comparative Biochemistry and Physiology Part B: Biochemistry and Molecular Biology 113, 795 801.

Hall, T. A. BioEdit: a user-friendly biological sequence alignment editor and analysis program for Windows 95/98/NT.(1999). Nucleic Acids Symposium Series 41, 95 98.

Heussen, C. and Dowdle, E. B.(1980). Electrophoretic analysis of plasminogen activators in polyacrylamide gels containing sodium dodecyl sulfate and copolymerized substrates. Analytical Biochemistry 102, 196 202.

Kraut, J.(1977). Serine protease: structure and mechanism of catalysis. Annual Review of Biochemistry 46, 331 358.

Kumar, S. - Nei, M. - Dudley, J. and Tamura, K. (2008). MEGA: a biologist-centric software for evolutionary analysis of DNA and protein sequences. Briefings in Bioinformatics 9, 299 306.

Livak, K. J. and Schmittgen, T. D.(2001). Analysis of relative gene expression data using real-time quantitative PCR and the 2(-Delta Delta $\mathrm{C}(\mathrm{T})$ ) Method. Methods 25, 402 408.

O’Brien, D. and McVey, J.(1993). Blood coagulation, inflammation, and defense. In: Sim E, editor. The natural immune systems, humoralfactors,, 257 280. NewYork : IRLPress.

Ovaere, P. · Lippens, S. • Vandenabeele, P. and Declercq, W.(2009). The emerging roles of serine protease cascades in the epidermis. Trends in Biochemical Sciences 34, 453 463.

Parry, M. A. · Fernandez-Catalan, C. • Bergner, A. • Huber, R. · Hopfner, K. P. · Schlott, B. · Gührs, K. H. • Bode, W.(1998). The ternary microplasminstaphylokinase - microplasmin complex is a proteinase - cofactor - substrate complex in action. Nature Structural Biology 5, 917 923. 
Perona, J. J. and Craik, C. S.(1995). Structural basis of substrate specificity in the serine proteases. Protein Science 4, 337 360.

Petersen, T. N. • Brunak, S. • von Heijne, G. and Nielsen, H.(2011). SignalP 4.0: discriminating signal peptides from transmembrane regions. Nature Methods 8, 785 786.

Piao, S. - Kim, S. · Kim, J. H. · Park, J. W. - Lee, B. L. and Ha, N. C.(2007). Crystal structure of the serine protease domain of prophenoloxidase activating factor-I. The Journal of Biological Chemistry 282, 10783 10791.

Piao, S. - Song, Y. L. - Kim, J. H. • Park, S. Y. • Park, J. W. - Lee, B. L. - Oh, B. H. and Ha, N. C.(2005). Crystal structure of a clip-domain serine protease and functional roles of the clip domains. The EMBO Journal 24, 4404 4414.

Powers, J. C. • Asgian, J. L. • Ekici, O. D. and James, J. E.(2002). Irreversible Inhibitors of Serine, Cysteine, and Threonine Proteases. Chemical Reviews 102, 4639 4750.

Proudfoot, N. J. and Brownlee, G. G.(1976). 3' non-coding region sequences in eukaryotic messenger RNA. Nature 263, 211 214.

Rawlings, N. D. and Barrett, A. J.(1993). Evolutionary families of peptidases. Biochemical Journal 290, 205 218.

Saitou, N. and Nei, M.(1987). The neighbor-joining method: a new method for reconstructing phylogenetic trees. Molecular biology and evolution 4, 406 425.

Shimada, S. Yamaguchi, K. Takahashi, M. Ogawa, M.(2002). Pancreatic elastase IIIA and its variants are expressed in pancreatic carcinoma cells. International Journal of Molecular Medicine 10, 299 603.

Sonawane, A.·Jyot, J.· During, R.·Ramphal, R.(2006).
Neutrophil elastase, an innate immunity effector molecule, represses flagellin transcription in Pseudomonas aeruginosa. Infection and Immunity 74, 6682 6689.

Suzuki, T. - Srivastava, A. S. and Kurokawa, T. (2002). cDNA cloning and phylogenetic analysis of pancreatic serine proteases from Japanese flounder, Paralichthys olivaceus. Comparative Biochemistry and Physiology Part B: Biochemistry and Molecular Biology 131, 63 70.

Tani, T. Ohsumi, J. Mita, K. Takiguchi, Y.(1988). Identification of a novel class of elastase isozyme, human pancreatic elastase III, by cDNA and genomic gene cloning. The Journal of Biological Chemistry 263, 1231 1239.

Thompson, J. D. - Higgins, D.G. and Gibson, T. J.(1994). Clustal W: improving the sensitivity of progressive multiple sequence alignment through sequence weighting, position specific gap penalties and weight matrix choice. Nucleic Acids Research 22, 4673 4680.

Wan, H. · Korzh, S. · Li, Z. • Mudumana, S. P. • Korzh, V. · Jiang, Y. J. - Lin, S. and Gong, Z.(2006). Analyses of pancreas development by generation of gfp transgenic zebrafish using an exocrine pancreas-specific elastaseA gene promoter. Experimental Cell Research 312, 1526 1539.

Zhang, W. J. Wei, H.·Frei, B.(2008). Ivermectin inhibits LPS-induced production of inflammatory cytokines and improves LPS-induced survival in mice. Inflammation Research 57, 524 529.

- 논문접수일 : 2014년 06월 05일

- 심사완료일 : 1차 - 2014년 07월 07일

- 게재확정일 : 2014년 07월 09일 